\title{
'Difficult to imitate and impossible to equal': Byron, Burns, Moore and the Packaging of National Song
}

\author{
KIRSTEEN MCCUE
}

\begin{abstract}
In the early i8Ios, just before embarking on his Hebrew Melodies project, Byron engaged in a correspondence with the Scottish song editor George Thomson (I757-I85I). While Byron chose not to engage in Thomson's commission to write lyrics for his collections of Irish and Welsh songs, Thomson nonetheless published a number of Byron's extant lyrics across his collections over the succeeding decades. This article traces how this happened, looks at Thomson's final editorial choices and presentations of Byron's lyrics, and reflects on the role of Byron as national songster alongside Thomson's most significant poetic contributor, Robert Burns, and Byron's great singer/songwriter friend Thomas Moore.
\end{abstract}

Byron's comment, quoted in the title to this essay, appeared in a letter to the song editor George Thomson (1757-I85I) dated io September I8I3. ${ }^{2}$ When asked to provide Thomson with national song lyrics for his Select Collection of Original Irish Airs, Byron protested a lack of confidence in 'producing anything worthy'. He was capable, he wrote, of writing lyrics, but of an inferior quality that would only serve to 'disgrace beautiful music'. 'Burns in your country, and Moore in this' continued Byron, 'have shown that even their splendid talents may acquire additional reputation from this exercise of their powers'. ${ }^{3}$ And he concluded that these competitors were 'difficult to imitate and impossible to equal'. Consequently, Byron did not accept Thomson's invitation, but, with the permission of his publisher John Murray, Thomson did present several of Byron's extant lyrics with musical settings by Beethoven, Haydn and others over the next two decades.

Byron's notable deference to the prowess of Burns and Moore might be interpreted as naturally respectful, but this genre was not, as Byron pointed out to Thomson, 'a species of writing which I undervalue'. ${ }^{4}$ Far from lacking lyrical quality, Byron was already fêted for his lyrical skills and achievements.' His reluctance to take up Thomson's commission lies uncomfortably beside the creative momentum he brought to the Hebrew Melodies project, in which he engaged with Jewish composer Isaac Nathan and tenor John Braham just months after Thomson's initial letter. Indeed, Thomas L. Ashton's detailed account of the genesis of Hebrew Melodies suggests that it was most probably Thomson's repeated requests that resulted in Byron opening 'his mind to the idea of composition for music' and that it was Nathan who was to benefit. ${ }^{6}$ But Byron Journal 45.2 (2017) https://doi.org/I0.3828/bj.20I7.I8 


\section{Kirsteen McCue}

the social milieu of the moment deserves attention too. Byron's involvement in the Hebrew Melodies project was significantly linked to his connection with his Cambridge friend John Cam Hobhouse (whose chorister singing had so impressed the young Byron) and their mutual friend Douglas Kinnaird, the financial backer for the project. Moreover, this was the period during which Byron's friendship with Thomas Moore grew and there are numerous accounts of evenings eating, drinking, debating, visiting the theatre and singing songs. As Jeffery Vail has noted, the two writers were insep-

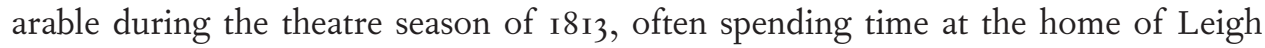
Hunt, whose musical soirées were famous and where Moore and Byron, in Hunt's view, 'harmonized admirably'. 'Vail's work, indeed, makes a convincing case for the lyrical influence of Moore over Byron at this particular moment in Byron's poetic development.

George Thomson's National Song project included major collections of Scottish, Welsh and Irish songs and involved his commissioning of more than thirty men and women writers of this period and a small number of key European composers. His six-volume Scottish collection ran from I793, soon after he started corresponding with Robert Burns, until the early i840s. In the intervening years Thomson produced two volumes of Irish songs (I8I4 and I8I6), three of Welsh songs (I809, I8I I and I8I7) and a six-volume octavo set incorporating songs from all three nations. There is no doubt that, from the start, Burns was Thomson's key lyricist (as well as a major source of melodic information); ${ }^{8}$ William Smyth (1765-1849), History Professor at Peterhouse College Cambridge, and author of English Lyrics (1797), is the only other writer with whom he corresponds on a similar level.

Thomson's editorial policy involved selecting the melodies he wished to include, commissioning his chosen composers to 'arrange' these for voice, piano, violin, 'cello (and sometimes flute) and to send, at the same time, copies of the melodies or descriptions of them to his selected lyricists. Clearly, having big names on board made a significant difference to Thomson's potential sales and gathering such celebrities was also useful in attracting other great artists to his project. The approaches to composers and poets alike were always flattering and informative; Byron was even used as a promotional 'hook' here. In the case of the composer Carl Maria von Weber, who agreed to work for Thomson's I826 edition of the Scottish folio collection, Thomson discussed the Edinburgh première of Weber's opera Der Freischütz in euphoric detail, and then continued his letter as follows:

I beg leave to inform you that I have for many years employed my leisure in collecting and publishing the National Melodies of Scotland, along with verses by our most celebrated lyric Poets, Burns, Scott, Byron \&c. My unbounded admiration for your illustrious countrymen, Haydn \& others induced me to request them to compose Ritornelles for introducing \& concluding each melody, and Accompaniments for the Piano forte, Violin, Flute \& Violoncello, to a great number of those Melodies, which they have done most happily. Admiring your genius no less, I am going to intreat that you will have the goodness to contribute your talents also to enrich the Work. 
Using Byron in this way belies just how difficult Thomson found it to induce the poet to work for his project. In his I898 study of Thomson's magnum opus, James Cuthbert Hadden gives a brief account of Thomson's correspondence with Byron. ${ }^{\text {I० }}$ Hadden indicates that it should be little surprise that Thomson was unsuccessful in securing Byron as a major contributor. The main body of their correspondence dates from the period July I8I2 until the summer of I8I 5, a time during which, Hadden states, Byron was 'sick both of himself and of poetry' and when he was longing to leave the British Isles." This view might be challenged as generalisation. Suffice it to say, during this three-year period Byron published the first two cantos of Childe Harold's Pilgrimage (March I8I2); engaged in at least two affairs as well as proposing to, marrying, having a daughter with and then separating from Annabella Milbanke; delivered two of his three addresses to the House of Lords (April I8I2 and June I8I3); published the Giaour (June I8I3) and both the musical and text-only editions of Hebrew Melodies (April and May I8I5). It would be the following April before he set out for Belgium, Germany and Switzerland.

By examining Thomson's letter-books alongside letters now held in the National Library of Scotland John Murray Archive in conjunction with Andrew Nicholson's edition of Murray's correspondence with Byron, several layers can be added to the story recounted by Hadden (see Table I): ${ }^{\mathrm{I}}$

\section{Table 2: Thomson-Byron-Murray Correspondence I8I2-I83I}

British Library George Thomson Letter-books (BL Add MS 35267); National Library of Scotland, John Murray Archive (NLS JMA: 43508 and 4I I 88); Murray's correspondence with Byron (ed. Andrew Nicholson, 2007: AN)

Thomson to Byron, io July I8I 2

Murray to Byron, 7 September I8I2

Thomson to Byron, 22 September I8I2

Murray to Byron, 28 September I8I2

Thomson to Murray, 30 November I8I 2 Thomson to Murray, 28 January I8I3 Thomson to Murray, 2 September I8I3
NLS JMA. $435 \circ 8$ is Thomson's letter of invitation sent to Byron; BL Add MS 35267, ff. $42-43$ is Thomson's fair copy

AN Letter 2, pp. 8-9: Murray notes that he has 'written to $\mathrm{Mr}$ Thomson in obedience to your Lordships [sic] wishes'

NLS JMA. 43508 is Thomson's letter to Byron; BL Add MS 35267, ff. 5I-52 is Thomson's fair copy

AN Letter 3, pp. I4-I5: Enclosing 'a communication from Mr G. Thomson of Edinburgh'; presumably Thomson's letter of 22 September listed above.

BL Add MS 35267, f. 62*

BL Add MS 35267, ff. 66-69**

NLS JMA. 4II 88 is the letter as sent to Murray; BL Add MS 35267, f. $8 \mathrm{I}$ is Thomson's fair copy 


\section{Kirsteen McCue}

Byron to Thomson, io September I8I3

Thomson to Murray, 8 October I8I3 Murray to Byron, [Dec I8I3-Mari8I4?]

Murray to Thomson, I March I8I5

Thomson to Murray, i6 July i8I 5

Thomson to Byron, 24 August I8I5

Thomson to Murray, 3 June I825

Thomson to Murray, I 7 July i 829

Thomson to Murray, 24 May I83I
$B L J$, 3, pp. II3-I4. Manuscript in Stark

Library, University of Texas.

NLS JMA. 4I I 88

AN letter 35, p. 85: Referring to Thomson's

letter to Murray of 2 September I8I3 about

permission to use three of Byron's songs.

NLS JMA. 4I I 88

NLS JMA. 4II 88

NLS JMA. 43508 is Thomson's letter to

Byron; BL Add MS 35267, f. 156 is Thom-

son's fair copy

NLS JMA. 4I I 88

NLS JMA. 4I I 88

NLS JMA. 4I I 88

* Not in the Murray Archive-fair copy only in Thomson's letter-books. There is a note on this letter stating that a similar letter was sent by Thomson to Murray on 8 January I8I3-but no copy of this letter has been found.

** Not in the Murray Archive-fair copy only in Thomson's letter-books.

Hadden explained that Thomson first contacted Byron on Io July I8I 2, having been impressed by Childe Harold. He sent the letter through Murray, with a copy of his collection, explaining that the national melodies of Scotland, Wales and Ireland have been set by 'the greatest musical professors' and the songs for them written by 'the most distinguished Poets'. He noted that Burns has been his 'chief Poet' and explained that his death had prompted Thomson to seek contributions from other writers including 'Walter Scott and Joanna Baillie'. He continued:

As variety, particularly variety of excellence, is very desirable, I have been anxious to grace my Work with some contributions from all the most eminent lyric Poets living. A few of the Melodies remain yet unprovided for, and, if I could prevail on your Lordship to take three or four of them into favour, and to match them with congenial Verses, I would be the happiest of men. ${ }^{13}$

Byron responded through Murray (though this particular letter is not extant) saying that he would like to be involved and Thomson then sent, again through Murray, a letter of 22 September I8I2 with five Irish melodies for Byron to consider. Thomson's account of how to create a national song is one he uses frequently in letters to poets:

Give me chance to mention, that for each Air, it is desirable to have Sixteen lines at least, though I care not how much longer the Songs may be. Let me also suggest that your Lordship should find it proper to introduce any Name, river, lake or mountain, or any local circumstance whatever, it should be taken from the native country of the Melodies.

I know not whether your Lordship happens to read Music, but altho' you do not, it is in the present case of very little or no consequence, because I have mentioned what appears to me the general character of each Air. Yet I am sensible that the true character of some airs is not easily ascertained, and therefore in writing Verses for national Melodies, 
much latitude is allowed to the Poet in chusing [sic] the subject or character of his song. He is fetter'd only in the measure, which must precisely correspond with the examples; these examples are put down solely as guides to the measure and not from any consideration as to their fitness or unfitness in regard to Subject, which I leave entirely to the good pleasure of the Muse. ${ }^{14}$

While Thomson reminded Murray (in November I8I2) that he was keen to receive Byron's contribution, it was not until January I 8I3 (this letter is missing) that Thomson received word that Byron entertained some doubt about his involvement. It is clear from Thomson's response to this letter that Byron had some concerns about being asked to write lyrics to match Irish airs for which his good friend Thomas Moore had already provided texts. He is thus referring to Moore's pivotal role in the Power brothers' Irish Melodies series, which had begun to appear in I807. Thomson's opinion is that other sets of lyrics can be supplied without worry: 'Mr Morre [sic] has furnished verses to Power for the very same airs [,] for which the verses of Burns were previously written and printed in my Work. [sic] and with this I find no fault'. He continued 'different songs can be perfectly well applied to the same Air, and each give delight to the heavens'. Thomson was convinced, indeed, that Power had taken his cue from him, telling Byron that his 'work was announced to the public to be in preparation several years before Power thought of his Irish airs'. ${ }^{15}$ To satisfy Byron, Thomson sent (with his January letter) airs that had not so far appeared in the Power brothers' collection. But nothing was forthcoming. Thomson sadly concluded, in his letter to Murray of 2 September I8I3, that he must 'now apply elsewhere'. In the same letter he ventured to clinch a deal with Murray to use some of Byron's already-published lyrics, naming three texts he was keen to include: 'Loch na Garr', 'Oh had thy fate been joined with thine' and 'The kiss, dear maid, thy lip has left'. ${ }^{16}$ Byron made contact directly with Thomson on Io September I8I3. This is the letter in which he comments on his inferiority to Burns and Moore and where he claims that, although he has tried to supply Thomson with suitable lyrics, he has been unable to 'satisfy myself'. ${ }^{17}$ Murray did give permission for Thomson to print his chosen Byron texts and they duly appeared across his Scottish and Irish collections (see Table 2 below).

In Hadden's account the remaining information about the collaboration with Byron is found in Thomson's letter to the poet of 24 August I8I5. By this time Byron had created his lyrics for Hebrew Melodies with music by composer Isaac Nathan. Thomson's letter refers to them as being 'diamonds of the first water' and that he has 'not words to express my admiration'. '8 Building on this compliment Thomson tries again to invite Byron to help with the final volume of his Select Collection of Original Welsh Airs. Thomson receives no response then or in the future, ${ }^{19}$ but the remaining letters in the John Murray Archive illustrate that the connection between Thomson and Murray continued. Even before writing to Byron in August, Thomson had already sent a copy of the first volume of his Select Collection of Original Irish Airs to Mrs Murray (I6 July I8I5), commenting that the delay of about eighteen months in publishing the volume had been because Thomson was holding out for Byron to deliver. Excepting 


\section{Kirsteen McCue}

one letter in February I8I6, ${ }^{20}$ when Thomson once more expresses his disappointment in failing to secure Byron as a contributor, there are three further letters to Murray dating from I825 to I83I. Thomson sent copies of his octavo collection in I825 and of the Scottish folio volumes in I83I, as his new edition in that year included some of Byron's songs. While there appear to be no further letters of permission from Murray, Thomson's letter to him of 24 May i83 I does state:

Nothing could be more obliging nor gratifying than the frank manner in which you permitted me to use such songs of Lord Byron as suited my Melodies: You will see that I have availed myself of several of them, which I hope one of your young Ladies will sing \& play to you at convenience, and not without giving you pleasure from the deep pathos with which they are fill'd. ${ }^{21}$

Though he contacted Byron initially around the time of compiling his first Irish volume, Thomson published only one of Byron's texts in this collection: 'The kiss dear maid thy lip has left' appeared in Volume 2 of I8I6 with a setting by Beethoven of a tune that had been 'communicated without a name by a friend'. ${ }^{22}$ Byron's lyric appeared again some years later in the second volume of Thomson's i83 I folio Melodies of Scotland, with an attractive and previously unpublished arrangement of the Irish air 'Gramachree' by Joseph Haydn. ${ }^{23}$ After combining songs from Scotland, Ireland and Wales in his I820s octavo volumes, Thomson was less worried about dropping a few Welsh or Irish songs or melodies into the later Scottish folio volumes. ${ }^{24}$ Byron's 'The kiss dear maid' did capture the musical imagination and two other contemporary settings exist: the first, interestingly by Isaac Nathan, and a second by theatre composer Jonathan Blewitt (I782-I853) who worked at Drury Lane in the I820s. ${ }^{25}$

While 'The kiss dear maid' appeared soon after Thomson's initial invitation to Byron, the other Byron songs did not appear until several years later. Across Thomson's collections seven of Byron's lyrics appeared, listed below in Tables 2 and 3:

Table 2

\section{First line of Byron lyric Citation in Thomson's Folio Collections}

The kiss dear maid thy lip A Select Collection of Original Irish Airs, I8 I6, II, no. 37, has left 90 [Beethoven] \{and later in Melodies of Scotland, I83 I, II, I8\} [Haydn]

Oh! Had my fate been join'd with thine

Farewell! If ever fondest prayer

I saw thee weep
A Select Collection of Original Scottish Airs, I8I8, V, 2I4 [Beethoven]

A Select Collection of Original Scottish Airs, I826, V, 226 \{also found in Twenty Five Additional Scottish Airs... entered Stationers' Hall 4 January I827\} thereafter as 204 in Vol V of Melodies of Scotland, I83 I [Hummel] A Select Collection of Original Scottish Airs, I826, V, 230 [melody by George Thomson - setting by Hummel] \{also found in Twenty Five Additional Scottish Airs, 230\} 
If sometimes in the haunts Melodies of Scotland (folio), I83 I, III, I I4 [Haydn] of men

Bright be the place of thy Melodies of Scotland (folio), I83 I, III, I I8 [Haydn] soul

Away, ye gay landscapes! Volume Sixth of Melodies of Scotland, I84I, 296

\{'Added to this work in 1838 '\} [Beethoven]

Table 3

First line of Byron Lyric

The kiss dear maid thy lip has left

I saw thee weep

Away, ye gay landscapes! [Sweet Annie]

\section{Citation in Thomson's Octavo Collection}

The Select Melodies of Scotland Interspersed with those of Ireland and Wales [...], I822-23, III, 4I [Kozeluch]

The Select Melodies of Scotland Interspersed with those of Ireland and Wales [...], I822-23, IV, 40 [melody by George Thomson — no composer named (but not the same as folio Hummel setting)]

Thomson's Collection of the Songs of Burns [...] United to the Select Melodies of Scotland and of Ireland and Wales [...] I 825, VI, 4-8 [Beethoven]

Thomson's choices ultimately embraced his favourite Byron works. 'The kiss dear maid' and 'If sometimes in the haunts of men' were taken from the poems printed alongside Cantos I and II of Childe Harold in the numerous editions of I8I2 and I8I $3 .{ }^{26}$ 'Farewell! If Ever Fondest Prayer' had appeared at the end of the I8I4 edition of The Corsair. The final section of 'Fugitive Pieces' published in the Hours of Idleness of 1807 , had supplied him with two texts: 'Oh! had my fate been join'd with thine' and 'Lachin Y Gair' or 'Loch na Garr'. '27 'Bright be the place of thy soul' was in the 'Stanzas to Music' first published in The Examiner on I I June I8I5. This text was set to music the same year by Isaac Nathan and also picked up by composer John Clarke for his Twelve Vocal Pieces (18I7) to which Walter Scott, James Hogg and Joanna Baillie (all key lyricists in Thomson's project) had contributed. It's likely that Thomson knew the song from the Clarke volume, but he may also have found the text in Byron's Poems of I8I6. It is not known if Thomson used the early text-only or musical publication of Hebrew Melodies, but he did select the lyric beginning 'I saw thee weep' for his octavo collection in 1822-23. He then republished the song in his Appendix of Twenty-Five Additional Scottish Airs in I826 and printed it in the I826 fifth folio volume. This later appearance uses a melody written by Thomson himself with a new musical setting by Johann Nepomuk Hummel. Thomson often supplied alternative lyrics for the same musical setting (his early Scottish volumes frequently presented a lyric in standard English as an alternative to a first text in Scots). In this case Byron's text appears alongside Burns's 'Farewell, dear mistress of my soul' (better known by its first line 'Clarinda, Mistress of my soul') and Sheridan's 'I have a silent sorrow here'. Examination of the early 


\section{Kirsteen McCue}

editions that it is likely Thomson consulted reveals that only orthographic changes or slight variants are made to Byron's printed texts. There are two exceptions to this. 'On Parting', beginning 'The kiss, dear maid! Thy lip has left', loses one of its stanzas (stanza 4). Thomson's editorial note explains that the melody he has chosen for the text requires an 8-line stanza and so he needed to remove four lines for it to fit his musical setting. The other exception is his major editing of 'Loch na Garr'.

'Lachin Y Gair', is perhaps the only obvious choice for a national collection like Thomson's. It has drawn particular attention for its Ossianic overtones, though Jerome McGann has indicated that it is actually more closely inspired by Thomas Campbell's 'Exile of Erin' of I80I. ${ }^{28}$ It is the only overtly Scottish song that Byron wrote and his footnote on its first printing made mention of his own ancestors, the Gordons. Indeed, part of the song's success is that combination of personal connection and love of place. Thomson did not print the text in full. Commenting alongside the lyric that 'The Editor regrets that he has not room for the intermediate stanzas of the noble author', he had in fact intended to publish only the first three verses. ${ }^{29}$ In the end he published verses $\mathrm{I}$ and 2 with the final verse-all of them nostalgic verses about the mountain. He makes further changes to the text, but most of these are insubstantive variants such as removing the exclamation marks in the opening line of the first stanza and in 1.5 and changing 'round' to 'Around' and 'Though' to 'tho' in 1.6. In 1.4 Thomson prints 'For still they are sacred to freedom and love'. While he misspells 'Garr' in verse $\mathrm{I}$, he prints it correctly in verses 2 and 3 and he hyphenates the title within his text, but otherwise this too is faithful to Byron.

Thomson appears to have struggled to make up his mind about the musical setting for Byron's song. As Barry Cooper has already deciphered, the combination of Beethoven's musical setting with Byron's lyric was a typical Thomsonesque mix-up..$^{30}$ Thomson sent his European composers a brief description of the subject of the song for which he intended their musical setting, but, as lyrics were frequently with a writer at this point in the process, the composer did not see a final text. In this particular case Thomson was intending Beethoven's setting for the Scots song 'Sweet Annie frae the sea beach came'. But he must also have intended to publish it with English verses by William Collins (I72I-59) beginning 'To fair Fidele's grassy tomb', for he sent Beethoven a description of the Collins text rather than the Scots song. He referred to it as a 'lamentation on the death of a beautiful girl' intended for the melody titled 'Sweet Annie'. ${ }^{1}$ Beethoven responded by producing a mournful setting of the melody (thought to be by English composer Maurice Greene) in the minor key. ${ }^{32}$ By the time Thomson decided to print it he had changed his mind about the text and chosen Byron's 'Loch na Garr' instead. Beethoven's setting of 'Sweet Annie' really suits the tenor of Byron's lyric most effectively. There are tonal similarities in the mood of both texts. Annie is lamenting the absence of her lover Jocky, as she struggles to avoid the advances of his older friend Jamie; Byron is lamenting the separation from his favourite place and its familial connections. Cooper rightly comments that Beethoven's arrangement suits well the 'poet's sense of being bereft of his beloved mountain and the land of his 
forebears' and he even suggests that the opening of the melody (it rises rather majestically and drops again) 'outlines the shape of a mountain'..$^{33}$

Thomson appears to have been pipped at the post in terms of being the first to publish Byron's song with music. As Cooper has identified, another musical setting of the text had appeared just a few months earlier in Robert Archibald Smith's Scotish [sic] Minstrel. ${ }^{34}$ Unlike Thomson, Smith includes all five stanzas of Byron's lyric, with some emendations: 'dear are thy mountains' rather than 'belov'd' in the first stanza; 'As daily I stray'd' not 'strode' in the second; and changing 'dark Loch na Garr' to 'wild' in the last line of verse 4 . This appearance uses an unnamed but sweeping and majestic melody that is still commonly sung today. Cooper also mentions a later appearance of Byron's song with this melody in John Greig's Scots Minstrelsie: A National Monument of Scottish Song (1893). While Smith's publication gives no additional information about the melody, Grieg states that this triumphant tune was composed by Mrs Partick Gibson (née Isabella Mary Scott), born in Edinburgh in 1786. A lady of literary and musical fame (she was apparently an 'accomplished harpist'), she was believed to be 'distantly related to Sir Walter Scott'. ${ }^{35}$

But neither Smith nor Thomson were the first to present the song to the musical public, for a single song-sheet exists with an arrangement by London theatre composer Henry Bishop: 'Loch na Garr / A favourite air with an Accompaniment for the / Harp or Piano Forte / Sung by Mrs Mountain / with Unbounded Applause at the / Public \& Private Concerts, / Composed by / Henry R. Bishop.' It was printed and sold for the author by L. Lavenu of 26 Bond Street, who was based at this address from I805. As the text did not appear in print until 1807 , the song must have appeared between then and Lavenu's move to no. 28 Bond Street in I8II. ${ }^{36}$ Bishop is famed for his hit 'Home Sweet Home' and there are some similarities to his tune for 'Loch na Garr', with its triplet semiquavers in the accompaniment, well suited to the harp. ${ }^{37}$ It's not as striking a melody as those published by Thomson or Smith, and the melancholic mood of Beethoven's arrangement is lost in the Bishop setting. But Bishop's melody, like the others, rises proudly with the first phrase of Byron's text and there are moments of darkness well-suited to the stormy landscape described. Bishop uses only the first three stanzas of Byron's text (which was Thomson's initial plan) and, with the exception of some orthographic changes (removal of exclamation marks in stanza I for example), he is faithful to Byron's lyric.

It is sad that Byron failed to respond more positively to Thomson's commission. Alongside the energy he brought to the Hebrew Melodies project, such a contribution would allow a more detailed comparison with the significant song corpus of Burns and Moore. Byron's comment on the superiority of these songster poets is, in one sense, understandable. Even allowing for the political stimulus for Hebrew Melodies, Byron did not work with song in quite the same ways as either his Irish or Scottish counterparts. The core of song-writing for Burns and Moore was directly connected to major national cultural projects in which the Power brothers, Thomson and James Johnson, amongst others, were playing a central facilitating role. Moreover, both Burns and Moore were 


\section{Kirsteen McCue}

completely bound up with the musical component of song. As well as his prowess as a performer, Moore's activity as a song-writer was inspired by Edward Bunting's transcriptions of Irish melodies gathered at the Belfast Harp Festival in $\mathbf{1 7 8 2} .^{38}$ Indeed, the success of the Power's publishing project resulted in Moore's lyrical texts becoming known as 'melodies'. Burns, as he noted in his letter to Thomson of September I793, began with a melody. Without the mood, tone, structure and rhythm of a tune, he was unable to begin to write a lyric to match. ${ }^{39}$ The creation of lyrics for Hebrew Melodies did involve intense (if short-lived) collaboration between Byron and Nathan, but the details of that working relationship are not fully explained by poet or composer. ${ }^{40}$ Byron, especially in the early I8Ios, was surrounded by performances of poetry in the theatre and in the drawing room and was deeply affected (as were so many) by Moore's powerful performances of his own songs. But there is no evidence to suggest that melody played the same role in Byron's creative process. Arguably, Byron's prowess as a lyricist is best displayed within larger poetic narrative frameworks.

Tom Mole's exploration of Hebrew Melodies offers another perspective on Byron's song-writing. ${ }^{41}$ Mole argues that Byron's wish to deviate from and experiment with a new form and new ideas caused Murray considerable challenges in branding his key poet at this moment in his career. Certainly, Murray's letter to Thomson of I March I8I5, but a month before Nathan's musical publication of Hebrew Melodies, notes his frustration. Interestingly Murray clearly saw benefits in Byron's involvement with a British collection like Thomson's in preference to his chosen collaboration with his Jewish peers Nathan and Braham:

I am more grieved that $[\mathrm{sic}]$ you imagine at the omission of one great writer amongst them — where he had far better appeared than in some Stupid Hebrew Melodies to which as a sort of Charity Lord Kinnairds brother induced him to write no less than I2 exquisite poems - I have not the most distant connexion with the publication \& although I am now publishing a compleat collection of Lord B's Works - They will not be contained in them. ${ }^{42}$

But they were. Murray's business acumen told him that inclusion or 'containment', as Mole calls it, was the best option here, and the texts of Hebrew Melodies appeared quickly in his four-volume collected edition of Byron. Murray's removal of the texts from their musical context at this point was pivotal in terms of Byron's role as a song writer. The separation of these songs from their musical environment caused untold problems with sales of the recently published musical settings and the ensuing unpleasantness with both Nathan and Braham may well have deterred Byron from further dealings with songs for performance. That said, Byron's personal circumstances were to change dramatically and almost simultaneously as he set sail for the continent. Had he stayed, would he have ventured further into the world of national and domestic song culture? Certainly, comparable opportunities seem not to have presented themselves in quite the same way thereafter.

For whatever reasons, Byron stepped away from song-writing for singing. But the musical lives of his texts, as shown so convincingly by Gooch and Thatcher, 
continued. ${ }^{43}$ As the nineteenth century progressed, the number of musical settings of Byron's work exceeded those of any other Romantic writer except Robert Burns. Thomson's collections with their musical settings by Haydn, Beethoven, Hummel and others became quickly outdated by the new and more sensational music of Rossini and his contemporaries. However, it is notable that Thomson's initial choice of key Byron texts for singing didn't become outmoded. Rather, it was this group of Byron songs that continued to be published with music and sung across the century.

University of Glasgow

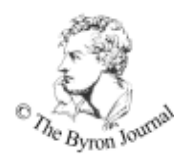

I The key research for this paper was undertaken within the remit of the AHRC-funded 'Editing Robert Burns for the $2 \mathrm{I}^{\text {st }}$ Century' project based at the University of Glasgow.

$2 B L J, 3$, pp. II3-I4.

3 Ibid. Marchand's note to the letter states that Thomson had published Thomas Moore's Irish Melodies in I807. This is erroneous. Moore's Melodies were published by J. and W. Power in London in that year. It is notable that Byron refers to Moore as being of 'this country', namely England, when his contribution is to Irish National song culture.

4 Ibid., p. II4.

5 Jerome McGann notes that 'Although academic criticism in the twentieth century has maintained a studied disinterest in Byron's lyric poetry, nineteenth-century attitudes were (as usual) very different'. McGann, Byron and Romanticism (Cambridge: Cambridge University Press, 2002), p. 93.

6 Thomas L. Ashton, Byron's Hebrew Melodies (London: Routledge \& Kegan Paul, 1972), pp. 19-20.

7 See Jeffery W. Vail, The Literary Relationship of Lord Byron \& Thomas Moore (Baltimore \& London: Johns Hopkins University Press, 200I), p. 5. Vail quotes from The Autobiography of Leigh Hunt, ed. by J.E. Morpurgo (London: Cresset Press, I949), p. 315. Chapter three of Vail's study concentrates on the writers' engagement with 'Nationalism, Music, and Poetry', pp. 8I-IO2.

8 Burns's letters to and from Thomson had appeared as volume 4 of James Currie's pivotal Life and Works of Robert Burns in I800. The manuscript of Burns's side of the correspondence is located as the Dalhousie manuscript at the Pierpont Morgan Library in New York, but Thomson's manuscript letters have disappeared. Currie's edition provided both sets of letters as edited by himself and Thomson.

9 Letter from Thomson to Weber of I8 January I825: BL Add MS 35268/I37-39.

Io James Cuthbert Hadden, George Thomson The Friend of Burns (London: John C. Nimmo, I898). The section on Byron is at pp. I87-93.

II Ibid., p. I87.

I2 See The Letters of John Murray to Lord Byron, ed. by Andrew Nicholson (Liverpool: Liverpool University Press, 2007).

I3 Letter from Thomson to Byron (via John Murray) of Io July I8I2: NLS, John Murray Archive [JMA] - MS 43508. Fair copy of this letter is in Thomson's letter-books at the British Library: BL Add MS 35267, ff. $42-43$.

I4 Letter from Thomson to Byron, via John Murray: NLS JMA, MS 43508. No melodies or examples are included in this letter, but they are listed in Thomson's letter-books: BL Add MS 35267, ff. 5I-2 (f. 52r). The five airs were: 'Dermot \& Sheila', 'Kitty of Colraine', 'The legacy', 'Avenging and Bright' and 'The Brown Maid'.

I5 Leith Davis also believes this to be the case: see Leith Davis, Music, Postcolonialism and Gender: The Construction of Irish National Identity, $2724-1874$ (Indiana: University of Notre Dame Press, 2006), 


\section{Kirsteen McCue}

pp. I4I-42. Quotations here are from Thomson's fair copy of his letter to Murray dated 28 January I8I3: BL Add MS 35267, ff. 66-69.

I6 Letter from Thomson to Murray of 2 September 1813: NLS, John Murray Archive, MS 4II88. Fair copy of this letter: BL Add MS 35267, f. 8I.

I7 Letter from Byron to Thomson of Io September I8I3, in $B L J$, 3, pp. II3-I4.

I8 NLS JMA MS 43508 is the original letter. Thomson spells the poet's name 'Biron' on the address.

I9 Letter from Thomson to Byron of 24 August I8I5: BL Add MS 35267, f. I56. See Hadden, p. I93.

20 Letter from Thomson to Murray of I4 February I8I6: NLS JMA MS 4II88.

2I See letter from Thomson to Murray of 24 May I83I: NLS JMA MS 4II88.

22 This was the term printed alongside the song in Thomson's volume: A Select Collection of Original Irish Airs, 2.37 (1816), p. 90.

23 Haydn had died in 1809 but this was one of several of his settings Thomson published posthumously. An alternative text by R.B. Sheridan beginning 'Had I a heart for falsehood framed' was given alongside Byron's lyric.

24 Irish airs were often regarded as a part of Scottish tradition and were found in collections of Scottish song and fiddle tunes in the long eighteenth century. Burns mentions Irish tunes several times in his letters to Thomson: see The Letters of Robert Burns ed. by G. Ross Roy (Oxford: Clarendon Press, 1985). See, for example, Burns's letters to Thomson in September I793 (Letter 586), 2, p. 243 and (Letter 589), 2, p. 252; or in November 1794 (Letter 646), 2, p. 326; and in May 1795 (Letter 664), 2, p. 350 .

25 See also his setting of James Hogg's 'Niddity Noddity Nanie' (better known as 'Auld Joe Nicholson's Bonny Nannie') in James Hogg, Contributions to Musical Collections \& Miscellaneous Songs, ed. by Kirsteen McCue (Edinburgh: Edinburgh University Press, 20I4), pp. 56I-67.

26 See above in NLS published I8I2 [GB. I246] includes Childe Harold Cantos I and 2 and some poems following these. 'On Parting' ('The kiss dear maid') appears on pp. I90-9I, but 'If sometimes in the haunts of men' does not appear in this first edition. It seems to have been added in the second edition as noted by McGann. See $C P W, 3$, p. 392. The text beginning 'If sometimes in the haunts of men' is no. I83.

27 Hours of Idleness, A Series of Poems Original and Translated by George Gordon, Lord Byron, A Minor (London: Murray, I807). 'Oh! Had my fate' appears on pp. I84-87 with 'Lachin Y Gair' on pp. I29-32.

28 See $C P W, \mathrm{I}, \mathrm{pp}$. I03-04. This text appears in Hours of Idleness of I807 on pp. I29-32.

29 See Thomson's letter to Murray of 2 September I813.

30 Barry Cooper, Beethoven's Folksong Settings: Chronology, Sources, Style (Oxford: Clarendon Press, 1994), pp. 80, 89. Cooper also discusses Byron on p. 70.

3I This is an often-anthologised and typically funeral lyric with much natural imagery and a certain gothic charm to it.

32 The melody was thought to have been composed by 'Dr Greene', namely the English composer Maurice Greene and it was selected by Joseph Ritson for his pivotal Scotish Songs of 1794. It also appeared in the first volume of James Johnson's (and Robert Burns's) Scots Musical Museum in I788 (no. 84). Murray Pittock's recent work on the song notes much earlier appearances from I730s onwards and that it is also in David Herd's collection which is probably how Burns came to know it. See The Scots Musical Museum, ed. by Murray Pittock for the new Oxford Works of Robert Burns (Oxford: Oxford University Press, forthcoming, 2018). While the text is in rich Scots the melody's English source caused William Stenhouse to note that this song was 'deservedly a great favourite on both sides the Tweed'. See: Illustrations on the Lyric Poetry and Music of Scotland (Edinburgh: William Blackwood \& Sons, I853), pp. 87-89.

33 Cooper, p. 9I.

34 R.A. Smith, The Scotish Minstrel A Selection from the Vocal Melodies of Scotland Ancient and Modern Arranged for the Piano Forte by R. A. Smith, 6 vols (Edinburgh: Robert Purdie, 1824) 6, pp. 38-39.

35 Scots Minstrelsie. A National Monument of Scottish Song, edited and arranged by John Greig, 


\section{Byron, Burns, Moore and the Packaging of National Song}

6 vols (Edinburgh: T.C. \& E.C. Jack, I893), 5, pp. I77-79. Greig's note cross-refers to R.A. Smith's collection and first appearance of the melody. Mrs Gibson died in I838.

36 See Charles Humphries \& William C. Smith, Music Publishing in the British Isles (London: Cassell \& Co. Ltd, 1954), p. 206.

37 See Richard Northcott, The Life of Sir Henry Bishop (London: The Press Printers Ltd., 1920). This is, to date, the only major study of Bishop and his work. Specific discussion of 'Home Sweet Home' can be found at pp. 74-78. General information for Bishop is found in Clive Brown's article on Sir Henry Rowley Bishop (1786-I855) for the online ODNB and Nicholas Temperley's updated 2013 entry for Sir Henry R. Bishop for the New Grove Dictionary of Music and Musicians now part of Oxford Music Online.

38 See Davis, Music, Postcolonialism and Gender, p. 95.

39 The Letters of Robert Burns, 2, pp. 239-48 (letter 586).

40 See A Selection of Hebrew Melodies, Ancient and Modern, by Isaac Nathan and Lord Byron, ed. by Frederick Burwick and Paul Douglass (Tuscaloosa \& London: The University of Alabama Press, I988), p. 8. The editors note that 'Nathan set poems he had been given and brought them to Byron, along with other tunes he had transcribed'. They suggest that composer played and poet listened, and that both created new music and new text as part of this process.

4I See Tom Mole, Byron's Romantic Celebrity: Industrial Culture and the Hermeneutic of Intimacy (Basingstoke: Palgrave MacMillan, 2007), chapter 6, pp. 98-II4.

42 Quoted from The Letters of John Murray to Lord Byron, p. I26. This quotation forms a footnote to Letter 65 of [Wednesday] II January I8I5 from Murray to Byron relating to Mr Kinnaird and permission for Murray to publish Hebrew Melodies.

43 See Bryan N.S. Gooch and David S. Thatcher, Musical Settings of British Romantic Literature, 2 vols (Garland publishing: New York \& London, I982), I. Byron's entries are listed on pp. $48 \mathrm{I}-600$.

This article was published open access under a CC BY license https://creativecommons.org/ licenses/by/4.0/ 


\section{JOIN THE BYRON SOCIETY AND RECEIVE TWO ISSUES OF THE BYRON JOURNAL A YEAR!}
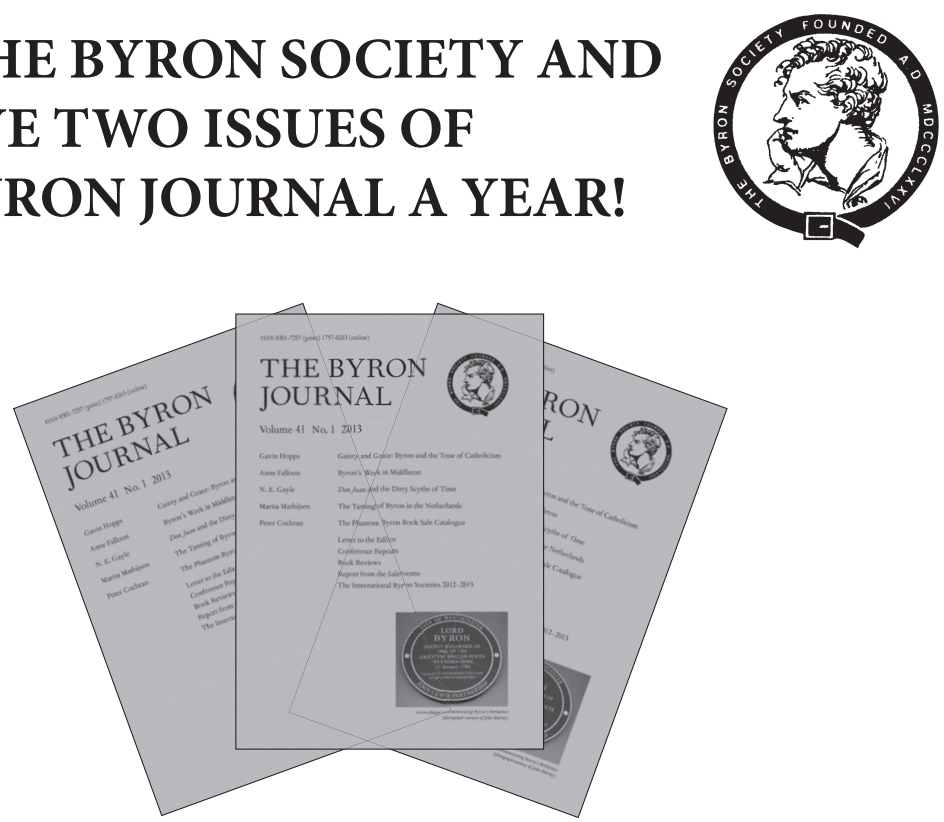

The Society welcomes applications for membership from all who are interested in Lord Byron's poetry and letters, his life and times, the Romantic Movement, and his continuing importance in the literary life of today.

Whether you are interested in the literary, academic or social activities of the Society you will find much to enjoy as a member. It costs $£ 30$ a year and in return you will receive two issues of the Journal and will be invited to take part in regular events in and around London, including lectures and dinners. As an additional benefit you will be supporting Byron scholarship.

Visit the website for details of forthcoming events:

www.thebyronsociety.com.

Please apply by email to thebyronsociety@btconnect.com, or in writing to:

The Byron Society

42 Walcot Square

London

SEI I 4TZ

UK

Members also have access to the journal's electronic backfile, dating back to 1973.

Liverpool University Press

4 Cambridge St $•$ Liverpool $\bullet$ L69 7ZU • UK

http://byron.liverpooluniversitypress.co.uk 